\title{
DOES LEVERAGE AFFECT LABOUR PRODUCTIVITY? A COMPARATIVE STUDY OF LOCAL AND MULTINATIONAL COMPANIES OF THE BALTIC COUNTRIES
}

\author{
Mari Avarmaa', Aaro Hazak², Kadri Männasoo ${ }^{3}$ \\ Tallinn University of Technology, Akadeemia tee 3, Tallinn, 12618 Estonia \\ E-mails:1'mari.avarmaa@nordea.com (correspondingauthor); ${ }^{2}$ aaro.hazak@tseba.ttu.ee; \\ ${ }^{3}$ kadri.mannasoo@tseba.ttu.ee
}

Received 07 April 2011; accepted 17 December 2011

\begin{abstract}
This paper investigates the impact of leverage on labour productivity of companies operating in the Baltic countries, with a focus on differences between local and multinational companies. We employ a fixed effects regression model on company level data, covering the period from 2001 to 2008. Our results demonstrate that the impact of leverage on labour productivity is non-linear and it differs dramatically between local and multinational companies. In the case of local companies, at low levels of leverage, an increase in external financing tends to bring along an improvement in labour productivity, while at higher levels of leverage an increase in debt financing appears to result in a loss of labour productivity. For multinational companies, the impact of leverage on labour productivity tends to be more linear and leverage appears to have a negative impact on labour productivity. Although debt overhang is believed to be an issue in the Baltic countries in general, local companies with low leverage might be able to increase labour productivity by additional borrowing.
\end{abstract}

Keywords: labour productivity, leverage, credit constraints, multinational companies, local companies, Baltic countries.

Reference to this paper should be made as follows: Avarmaa, M.; Hazak, A.; Männasoo, K. 2013. Does leverage affect labour productivity? A comparative study of local and multinational companies of the Baltic countries, Journal of Business Economics and Management 14(2): 252-275.

JEL Classification: G32, D24.

\section{Introduction}

Achievement of sustainable economic growth is a central goal for economies worldwide. The neoclassical growth theory drawn on the seminal work of Solow (1956) demonstrates that productivity growth is one of the main drivers for long-term GDP growth per capita. This relationship has found strong empirical support (e.g. Hall, Jones 1999; OECD 2003; Schadler et al. 2006; Arratibel et al. 2007). Understanding the determinants of productivity at a micro level as well as the related challenges and opportunities in a broader context are therefore key elements for exploring the paths for economic growth. 
While access to credit has, to a large extent, been seen as a prerequisite for economic success (King, Levine 1993), the recent lending booms have rather demonstrated the risks to company viability resulting from excessive debt financing, highlighted by the global crisis of 2008/09. The impact of leverage on productivity and long-term growth hence deserves closer scrutiny.

As a result of the ageing population, many European economies will be increasingly under pressure in the decades to come. Output growth needs to be achieved with limited increase in labour force and improvements in labour productivity are essential for sustaining growth ${ }^{1}$.

This paper focuses on company financing and ownership as determinants of labour productivity. Our aim is to study the relationship between leverage and labour productivity comparing the multinational companies (MNCs) and local companies. Although the areas of capital structure and productivity have both been widely researched, the linkage between company financing, ownership structure and labour productivity has received limited attention in previous literature.

The scarce previous empirical research on the impact of leverage on labour productivity is controversial. While one study (Nunes et al. 2007) has found the impact of leverage on labour productivity to be negative, others have identified a positive (Dimelis, Louri 2002) or non-linear relationship (Kale et al. 2007). We seek to add some new evidence to resolve the puzzle.

We also contribute to the literature by showing that the impact of leverage on labour productivity is different for local companies and MNCs. Although some previous research (for example a summary of which is presented in a review paper by Bellak 2004) has sought to identify the sources of productivity gap between local companies and MNCs, the impact of financing has been ignored.

Just like several other transition economies, the Baltic countries have been successful in attracting foreign investments. Empirical evidence shows that foreign direct investments play an important role in the labour productivity growth in the region (Bijsterbosch, Kolasa 2009). It would therefore be interesting to understand the drivers of labour productivity of multinational companies operating in the Baltic countries, and to identify whether these differ significantly from the determinants of labour productivity of local companies.

Empirical evidence indicates that MNCs in the Baltic countries have more flexibility in their financing decisions compared to local companies (Avarmaa et al. 2011). We seek to investigate whether such flexibility leads to any advantages for MNCs in achieving higher labour productivity. We perform a panel data regression analysis on a sample of 3,676 Baltic companies covering the period of 2001 to 2008 . According to our knowledge, this is the first empirical research on the relationships between leverage and productivity covering the three Baltic countries.

\footnotetext{
${ }^{1}$ Labor migration could be considered as alternative measure to relieve the shortage of labor force.
} 
The article is set up as follows: the next section provides overview of the literature on the relationships between leverage and productivity, as well as on the productivity differences between foreign and local companies, Section 3 presents the regression model and data, Section 4 explains our results, and the last section concludes the paper.

\section{Literature overview}

The classics of corporate finance theories offer some predictions on the influence of leverage on productivity. The agency theory of capital structure explains that debt functions as a monitoring device over managers (Jensen, Meckling 1976), meaning that higher debt levels might result in higher efficiency and productivity. The signalling theory of capital structure suggests that because companies which perform better use the issuance of debt as a signal about their quality (Ross 1977), higher debt might be associated with higher productivity. On the other hand, the debt overhang concept by Myers (1977) explicates that high leverage can cause companies to underinvest since the benefits of new capital investments accrue largely to debt holders instead of equity holders. Ultimately, this leads to weaker company performance. Coricelli et al. (2010) also point out that excessive leverage could lead to overcapacity and therefore result in lower productivity.

Concerning empirical research, several works show that leverage has a negative impact on productivity. Nucci et al. (2005), employing a sample of Italian companies, find a negative relationship between leverage and productivity. They show that there is a negative causal relationship from a company's leverage to its propensity to innovate, and that innovativeness leads to higher productivity. Ghosh (2009) makes a similar conclusion on a sample of Indian high-tech companies. Based on their quantile regression analysis of a sample of Portuguese companies, Nunes et al. (2007) also show that the relationship between leverage and labour productivity is negative, except for the most productive companies, in which case higher leverage tends to increase productivity. In contrast to the papers above, Kale et al. (2007), relying on a sample of US companies, find a positive concave relationship between leverage and labour productivity, which is in line with the agency theory. Hossain et al. (2005) analyse the components of productivity growth in US food manufacturing industry and find that increases in dividends contribute to the productivity growth, which, in its turn, is in line with the signalling theory.

Out of the limited research on the relationships between leverage and productivity as well as company ownership in Central and Eastern Europe (CEE), Coricelli et al. (2010) have focussed on the impact of leverage on total factor productivity (TFP) growth in twelve CEE countries (including Latvia) and found the relationship to be non-linear. The impact of foreign ownership on TFP growth appeared to be insignificant, except for the subsample with non-zero debt where a positive effect was found. Gatti and Love (2006), relying on a Bulgarian sample, find that access to credit is positively associated with productivity. Moreno Badia and Slootmaekers (2008) have investigated the relationship between productivity and financial constraints in Estonia. They conclude that financial constraints do not have an impact on productivity in most sectors, with the exception of R\&D, where financial constraints have a large negative impact on productivity. They find that companies with majority foreign ownership are more productive. 
Within the broad area of productivity related research, productivity differences between foreign-owned and domestically-owned companies have received increasing attention during the last two decades. Pfaffermayr and Bellak (2000) have summarised the main reasons for performance differences between foreign-owned and domestically-owned companies that have emerged from existing research. They have pointed out the following factors: the company-specific assets (such as production process, reputation or brand) of multinational companies transferred from and to affiliates; the more narrow specialisation of foreign-owned companies due to being part of a larger group; the access of foreign-owned companies to new technologies and opportunities for learning; different accounting practices, and different corporate governance structures. The review paper by Bellak (2004) provides a detailed discussion on the sources of productivity gaps between foreign-owned and domestic companies.

Empirical evidence on the productivity gap between foreign and domestic corporations is mixed, while the existence of such a gap tends to be supported. Girma et al. (1999) find that there is a productivity and wage gap between foreign and domestic companies in the manufacturing sector of the UK. Oulton (1998a) finds labour productivity of foreign manufacturing plants to be higher compared to the UK-owned plants as well as labour productivity of foreign companies to be better in the non-manufacturing sector in the UK (1998b). Greenaway et al. (2009) show that there is a U-shape relationship between foreign ownership and productivity in China, suggesting that foreign ownership is associated with improved performance only as long as it is accompanied by some degree of local participation. In their quantile regression analysis of foreign-owned and domestic corporations in Greece, Dimelis and Louri (2002) found that in the middleproductivity range, foreign companies exhibit higher efficiency while foreign ownership does not matter among the very productive and least productive companies. Nunes et al. (2007) show that foreign ownership increases labour productivity for all but the least productive companies in Portugal. However, in their plant-level comparative analysis of labour productivity in foreign and domestic establishments in Canada, Globerman et al. (1994) found no significant differences in productivity between these two groups after controlling for factors such as size and capital intensity.

There are some studies focusing on the performance of multinational versus non-multinational companies (as opposed to foreign versus domestic companies). Doms and Jensen (1998) find foreign-owned plants in the US to be more productive than the domestic ones, but less productive than the plants of US-owned multinational companies. Castellani and Zanfei (2004) arrive at a similar result for Italian manufacturing companies, showing that companies belonging to multinational groups outperform uninational companies. Pfaffermayr and Bellak (2000), in their study of productivity and profitability of Austrian companies, also conclude that performance gaps do not relate to the foreign ownership per se but rather to the gains from multinationality.

An area of research directly related to productivity differences is the study of productivity spillovers where the focus is on indirect benefits of FDI to productivity in the host country. Generally, productivity spillovers are said to take place when the entry or presence of MNCs leads to productivity or efficiency benefits in the host country's 
local companies, and the MNCs are unable to internalise the full value of these benefits (Blomström, Kokko 1998). In this area, several studies have been performed based on data from CEE countries. Vahter (2004) has studied the productivity spillovers in the manufacturing sector of Slovenia and Estonia and found that in both countries foreign companies exhibit higher labour productivity compared to domestic companies. Positive spillover effects were found only in Slovenia. Vahter and Masso (2006) have studied spillover effects in Estonia for 1995-2002 and found that foreign companies demonstrate higher total factor productivity than domestic companies and that the existence of spillover effects were mixed. Geršl et al. (2007) have investigated productivity spillovers in CEE countries and found that the effects differ across countries and depend on various company, industry and country specific characteristics.

Some authors have considered the impact of financing when analysing productivity gaps. Explaining the higher productivity of foreign companies operating in the UK compared to the local companies, Oulton (1998b) has pointed out that local companies might face higher cost of capital than foreign-owned companies while foreign companies are likely to be less constrained by the financial markets in the UK. Analysing productivity gaps in Greece, Dimelis and Louri (2002) have found a positive and significant effect of leverage as one of the control variables on labour productivity. Greenaway et al. (2009), on the other hand, have found no significant relationship between leverage and labour productivity on a Chinese sample of foreign and local companies.

In our study, we seek to link the relationship between financing and productivity with productivity gaps between foreign (multinational) and local companies. Our main focus is on the impact of leverage on the productivity of MNCs and local companies in the Baltic countries.

\section{The model and data}

\subsection{The model}

We use panel data regression analysis to study the determinants of labour productivity. Drawing on the work of Dimelis and Louri (2002), we use an augmented version of Cobb-Douglas production function for our empirical model. Just like these authors, we have included leverage as one of the independent variables. In order to allow for the differences in the impact of leverage on productivity between multinational and local companies, we have included an interaction term between leverage and a dummy variable for multinational companies. The model is complemented with additional control variables derived from the findings of previous research. We model labour productivity of an $i$-th company at time $t$ as follows:

$\log \left(Y / L_{i t}\right)=\beta_{1} G D P_{i t}+\beta_{2} L E V_{i t}+\beta_{3} L E V^{2}{ }_{i t}+\beta_{4} L E V \cdot M N C_{i t}+\beta_{5} L E V^{2} \cdot M N C_{i t}$ $+\beta_{6} C R E D_{i t}+\beta_{7} C R E D \cdot M N C_{i t}+\beta_{8} A G E_{i t}+\beta_{9} A G E^{2}{ }_{i t}+\beta_{10} S I Z E_{i t}+\beta_{11} T_{A N G}+$ $\beta_{12} H H I_{i t}+\beta_{13} L E V \cdot S K I L L_{i t}+a_{i}+u_{i t}$

where $\alpha$ denotes company-level fixed effects. The variables are explained in Table 1 below. 
Table 1. Variables used in the regression model

\begin{tabular}{l|l|l|l}
\hline Variable & $\begin{array}{l}\text { Abb- } \\
\text { reviation }\end{array}$ & Measurement & $\begin{array}{l}\text { Expected } \\
\text { sign }\end{array}$ \\
\hline Labour Productivity & $\ln$ (Y/L) & Ln (Real sales/number of employees) & $\begin{array}{l}\text { dependent } \\
\text { variable }\end{array}$ \\
\hline GDP Growth & GDP & Real GDP growth, data from Eurostat & + \\
\hline Adjusted Leverage & LEV & $\begin{array}{l}\text { (Short-term debt+Long-term liabilities)/(Total } \\
\text { assets-Current liabilities+Short-term debt) }\end{array}$ & non-linear \\
\hline Long-term Leverage & LEV & $\begin{array}{l}\text { Long-term debt/(Total assets-Current } \\
\text { liabilities+Short-term debt) }\end{array}$ & non-linear \\
\hline Credit Constraints & CRED & $\begin{array}{l}\text { Industry level value of credit constraints, data } \\
\text { from BEEPS }\end{array}$ & - \\
\hline Age & AGE & Number of years from incorporation & non-linear \\
\hline Size & SIZE & Ln of real total assets & + \\
\hline Tangibility & TANG & Fixed assets/Total Assets & - \\
\hline Herfindahl Index & HHI & $\begin{array}{l}\text { Squared sum of market shares in all firms in } \\
\text { the industry based on 2-digit US SIC codes }\end{array}$ & + \\
\hline $\begin{array}{l}\text { Skill-intensive } \\
\text { Industry }\end{array}$ & SKILL & $\begin{array}{l}1 \text { if belonging to skill-intensive industry, } \\
\text { otherwise 0 }\end{array}$ & + \\
\hline Multinationality & MNC & $\begin{array}{l}1 \text { if more than } 50 \% \text { owned by a foreign } \\
\text { company, otherwise 0 }\end{array}$ & + \\
\hline
\end{tabular}

We employ a fixed effects model since it helps to control for unobserved heterogeneity between the companies that is constant over time and correlated with independent variables. The Hausman test showed that a fixed effects model was to be preferred to a random effects model. Robust standard errors have been employed, which control for the bias in the presence of heteroskedasticity and for the within-cluster serial correlation.

There are various ways for measuring productivity. Syverson (2010) has brought out issues related to the measurement choice, concluding that the results of previous productivity research are generally not sensitive to the method of measuring productivity. The most common measure of productivity in company-level research appears to be total factor productivity (TFP) (e.g. Nucci et al. 2005; Ghosh 2009; Chen 2010; Coricelli et al. 2010). We, however, concentrate on studying labour productivity as one of the key factors for economic growth under the aging population. Several previous works on productivity have used value added per employee for measuring labour productivity (Globerman et al. 1994; Oulton 1998a, 1998b; Doms, Jensen 1998; Girma et al. 1999). Due to data limitations, we have not been able to calculate value added for our data set. Therefore, similarly to Dimelis and Louri (2002), and Pfaffermayr and Bellak (2000), logarithm of sales per employee was used as a measure of productivity $(Y / L)$. Since sales are influenced by inflation, real sales figures have been used. In order to arrive at real sales, industry-level price-index deflators obtained from Eurostat have been used.

The main independent variable of interest in our model is leverage ( $L E V)$. We have used two alternative measures for leverage in our regression. First, we have included 
an adjusted measure of leverage (see Table 1), calculated similarly to several studies on capital structure (Rajan, Zingales 1995; Jog, Tang 2001; Huizinga et al. 2008). This measure takes into consideration the fact that some assets on the balance sheet are offset by specific non-debt liabilities. To calculate leverage, previous studies on productivity have used either the ratio of short and long term debt to net worth (Dimelis, Louri 2002) or the ratio of total liabilities to total assets (Greenaway et al. 2009; Weill 2008). We believe that our approach represents a more appropriate measurement of leverage. To consider the specifics of long-term financing compared to short term financing, we have employed long-term leverage as an alternative to adjusted leverage. While long-term investments should generally be financed from long-term financial resources, long-term debt could be more difficult to obtain compared to short-term debt. We have used the same denominator for the long-term leverage as for the adjusted leverage due to the advantages of such measurement pointed out above.

As some of the previous works have identified a non-linear relationship between leverage and labour productivity (see Table 2 below), we have included both leverage $(L E V)$ and squared leverage $\left(L E V^{2}\right)$ in our regression model. The possible endogeneity of leverage was tested with Davidson-MacKinnon test and the exogeneity of leverage was supported.

Table 2. Summary of previous studies on the impact of leverage on productivity

\begin{tabular}{l|l|l|l}
\hline Authors & Producitivitymeasure & Formula for leverage & $\begin{array}{l}\text { Sign for } \\
\text { leverage }\end{array}$ \\
\hline $\begin{array}{l}\text { Dimelis and } \\
\text { Louri } 2002\end{array}$ & Labour productivity & $\begin{array}{l}\text { (Short-term debt + long-term debt)/total } \\
\text { assets }\end{array}$ & + \\
\hline $\begin{array}{l}\text { Nucci } \text { et al. } \\
2005\end{array}$ & TFP & Debt/total assets & - \\
\hline $\begin{array}{l}\text { Kale } \text { et al. } \\
2007\end{array}$ & Labour productivity & $\begin{array}{l}\text { (Book value of long-term debt }+ \text { short- } \\
\text { term debt) / (book value of debt }+ \text { market } \\
\text { value of equity) }\end{array}$ & non-linear \\
\hline $\begin{array}{l}\text { Nunes } \text { et al. } \\
2007\end{array}$ & Labour productivity & Total liabilities/total assets & - \\
\hline $\begin{array}{l}\text { Weill } 2008 \\
\text { Ghosh } 2009\end{array}$ & Cost efficiency & Total liabilities/total assets & $\begin{array}{l}\text { varies by } \\
\text { country }\end{array}$ \\
\hline $\begin{array}{l}\text { Greenaway } \\
\text { et al. } 2009\end{array}$ & TFP & Total debt/total assets & - \\
\hline $\begin{array}{l}\text { Coricelli } \\
\text { et al. } 2010\end{array}$ & TFP growth & Total liabilities/total assets & - \\
\hline
\end{tabular}

Some previous studies (Gatti, Love 2006; Moreno Badia, Slootmaekers 2008) have investigated the impact of either financial constraints or access to credit on productivity. We have used credit constraints $(C R E D)$ as one of the independent variables in the productivity regression. Similarly to the results of Gatti and Love (2006) who found access to credit to be positively related to productivity, we expect credit constraints to be negatively correlated with labour productivity. 
Real GDP growth (GDP) was added to control for the impact of economic cycles on labour productivity. The expected sign of the GDP growth variable is positive, as economic upturns should enable companies to expand sales and thereby improve productivity of labour.

Previous literature has brought out that larger companies tend to benefit from economies of scale. A comprehensive discussion of the reasons for the positive impact of company size on productivity is offered by Leung et al. (2008). Empirical evidence confirms this positive relationship (Dimelis, Louri 2002; Greenaway et al. 2009; Moreno Badia, Slootmaekers 2008). Company size has been measured in previous research mainly by the logarithm of total assets (Dimelis, Louri 2002; Männasoo 2008; Greenaway et al. 2009) or by the number of employees (Kale et al. 2007; Hazak, Männasoo 2010). We prefer the logarithm of total assets as in our case labour productivity is calculated based on the number of employees. In order to eliminate the impact of inflation, real values of assets have been used.

In order to control for the impact of the capital factor, we have included tangibility in the regression. The results of previous research are inconclusive regarding the relationship between tangibility and productivity. Weill (2008) has found a negative relationship between tangibility and cost efficiency in all of the seven European countries included in his sample. In addition to industry effects, he explains the relationship with the fact that a higher tangibility level means lower working capital and therefore lower managerial performance. Greenaway et al. (2009) have found a negative relationship between TFP and tangibility in China, while the influence of tangibility on labour productivity remained insignificant. In their quantile regression analysis on a sample of Portuguese companies, Nunes et al. (2007) found a negative relationship between tangibility and labour productivity in most cases, except for the companies with very high productivity. They explain the outcome with the tendency that companies with high R\&D investments tend to have less fixed assets. Chen (2010), on the other hand, has found a positive relationship between collateral (measured by tangible fixed assets by total assets) and TFP in China, but the magnitude of the impact was small. She concludes that companies' ability to collateralise external borrowing can improve their productivity.

As productivity is considered to vary by the overall level of innovativeness in the industry, the impact of leverage is observed separately for skill-intensive and non-skill intensive industries. We constructed a dummy variable for skill-intensive industries (SKILL) and interacted this with the leverage variable (LEV.$S K I L L)$. The classification of industries is based on the Pavitt taxonomy (Pavitt 1984) whereby industries are divided into four classes - scale-intensive, specialised suppliers, science based, and suppliers dominated. We consider the first three classes as skill-intensive. The concordance between the two-digit US SIC codes and Pavitt's categories is based on Greenhalgh and Rogers (2004). For the industries missing from the latter paper, we have used the classification according to NACE codes from Pianta and Bogliacino (2008).

Productivity is considered to be influenced by product market competition. A comprehensive discussion on the impact of competition on productivity is provided by Vahter (2006). 
He shows that in the empirical literature, a positive relationship between competition and productivity is generally found. To control for the intensity of product market competition, we have included the Herfindahl index $(H H I)$ as an independent variable, similarly to Kale et al. (2007). The index is calculated as a squared sum of market shares of all companies in the industry based on the 2-digit US SIC-codes. However, as Vahter (2006) has pointed out, the Herfindahl index is based on a certain classification of industries and thus could be misleading. In addition, the Herfindahl index might excessively emphasise large market players (see e.g. Ginevičius, Čirba (2009) among others). Since there is no other appropriate proxy for competition available, and considering the nature of the available data, we have used the Herfindahl index despite the potential drawbacks mentioned above.

Since the level of labour productivity tends to be industry-specific, we control for this impact by including interaction terms between year and sector dummies. For that purpose, we have divided industries into four sectors (manufacturing, trade, construction, and service).

We have divided the sample into two subsets - multinational and non-multinational companies. If more than $50 \%$ of a company is directly owned by a foreign company, it is classified as a multinational company $(M N C)$. Otherwise, the company is labelled as a non-multinational (i.e. local). The terms "local company" and "non-multinational company" are used interchangeably in this paper.

As the main focus of our article is the impact of leverage on productivity in the comparative perspective of multinational and local companies, and considering that multinationality does not vary much over time, we have interacted the MNC dummy with leverage $(L E V \cdot M N C)$ and the squared term of leverage $\left(L E V^{2} \cdot M N C\right)$. Avarmaa (2011) has found that the impact of credit constraints on the growth of local and multinational companies is different. We have therefore included an interaction term between credit constraints and MNC dummy (CRED - MNC) into the regression model. In order to test whether the coefficients for leverage, leverage squared, and credit constraints are significantly different for MNCs and local companies, the Chow test was performed. The independent variables were interacted with the MNC dummy and the interaction terms were included in the regression. The null hypothesis that the coefficients are equal was rejected with $5 \%$ significance.

\subsection{Data and descriptive statistics}

We have extracted data on companies operating in Estonia, Latvia and Lithuania from the Amadeus database compiled by Bureau van Dijk. The database provides financial statements and information regarding the ownership structure of private and publicly owned European companies. Our sample covers the period from 2001 to 2008. Companies in the public utilities and financial sector (US SIC codes 4000-4999 and 6000-6999) are excluded from the analysis due to their fundamentally different financial structure. Branches of foreign companies, cooperative companies and partnerships are also excluded from the sample since their legal form makes financial decision-making different from regular limited liability companies. Similarly to Weill (2008), unconsolidated data are used. For every company, data are included in the sample for those years for which financial information was available at a sufficient level of detail and all 
components of assets and liabilities were non-negative. In order to avoid the unjustified influence of outliers to the regression results, the upper $2 \%$ of observations of labour productivity were eliminated ${ }^{2}$. For the same reason, for companies established before 1991, we have counted their age starting from year 1991 when the Baltic countries regained their independence and the regulatory frameworks for operating a company were fundamentally changed. In case ownership data were missing for a certain year, the latest available information on ownership was used. The companies for which no data on the number of employees were available were dropped from the sample.

The data for perceived credit constraints have been obtained from the Business Environment and Enterprise Performance Survey (BEEPS) conducted by EBRD and the World Bank. The indicator has been composed by using the BEEPS 2002, 2005 and 2009 data on access to finance by applying a similar procedure as in Avarmaa et al. (2011) and Avarmaa (2011). Namely, the survey data provides companies' estimates regarding their ability to access finance in their country of operation on a scale of four levels ranging from "No obstacle" to "Very Severe Obstacle". The variable has been normalised, taking values between 0 and 1. The missing observations for the years 2003-2004 and 2006-2007 have been derived using the cubic spline interpolation technique. The observations for 2001 have been linearly extrapolated. The indicator allows for variance across industries and over time, and between MNCs and local companies.

As our focus is on the analysis of the labour productivity of multinational companies compared to non-multinationals, we aimed to have an equal number of multinational and non-multinational companies in the sample. We therefore included all multinational companies that met our criteria and randomly selected the same number of local companies from each of the three countries. As a result, our sample consists of 18,401 company-year observations whereof $50 \%$ belong to multinational companies. $50 \%$ of observations are from Estonia, 26\% from Latvia, and 24\% from Lithuania. The total number of companies included in the sample is $3,676^{3}$.

Appendixes 1-3 provide descriptive statistics regarding the two subsamples. On average, MNCs appear to be twice as productive as the non-multinational companies operating in the Baltic countries - the mean value of real labour productivity of nonmultinationals is 83 thousand Euros per employee compared to 152 thousand Euros in multinationals. It becomes evident that MNCs are generally considerably bigger than local companies in terms of sales, assets and headcount but are relatively less leveraged and carry relatively less tangible assets. As discussed in Section 4, the different size and productivity levels for MNCs compared to local companies tend to have an impact on the relationship between leverage and labour productivity.

Average labour productivity by company age is presented in Figure 1. The figure reveals that for both local companies and MNCs labour productivity increases rapidly after the start-up phase and starts decreasing gradually thereafter.

\footnotetext{
${ }^{2}$ As the distribution of labour productivity is skewed to the right, there was no need to remove outliers from the left side of the distribution.

${ }^{3}$ When using the whole sample, the regression results were qualitatively the same.
} 


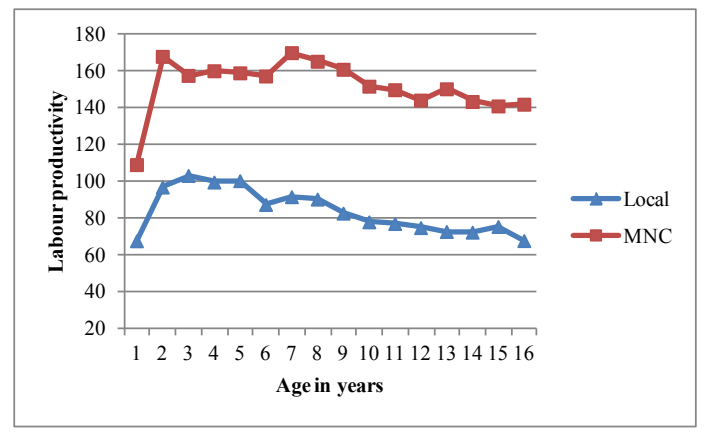

Fig. 1. Labour productivity (in thousands of Euros) by company age

Average labour productivity has been constantly growing throughout the nine years in the Baltic countries (Fig. 2), especially for local companies. At the same time, average leverage has not increased considerably. There is a slight upward trend for both adjusted leverage and long-term leverage of local companies in the boom years of 2005 to 2007, and a respective drop in 2008, in accordance with the financial and economic crisis. Trends of average leverage of MNCs, on the other hand, are relatively stable throughout the years under review.
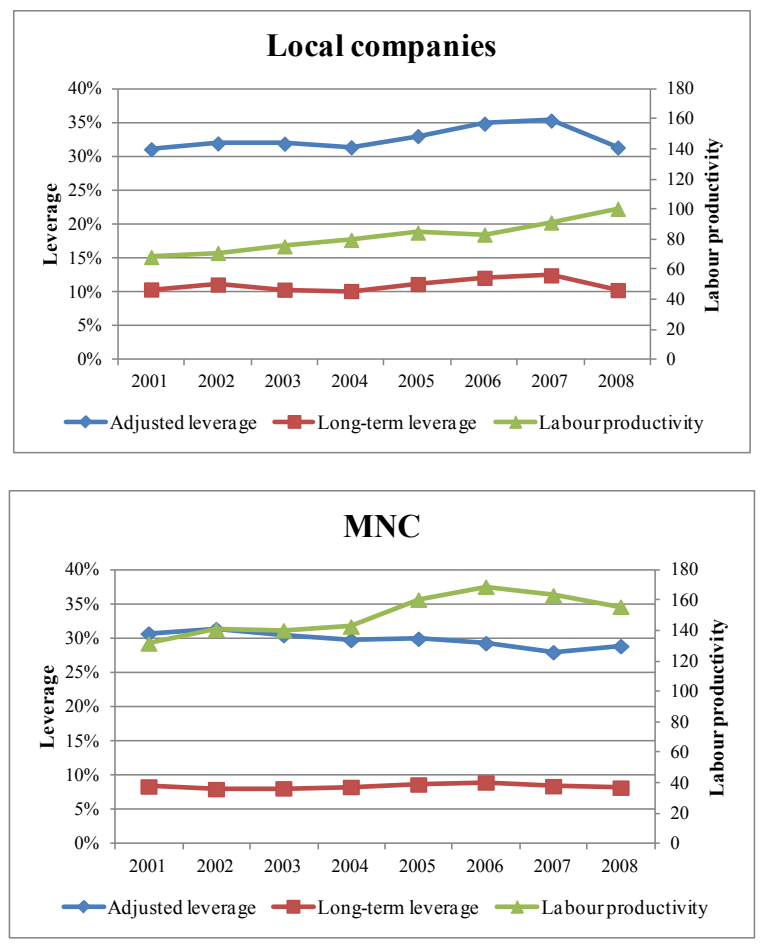

Fig. 2. Average labour productivity (in thousands of Euros) and leverage of multinational and local companies by years 
Average labour productivity calculated for ten leverage brackets with a step of $10 \%$ (Fig. 3) indicates that the relationship between leverage and labour productivity tends to be non-linear and the nature of this relationship seems to differ for local and multinational companies. The nature of this relationship is to be studied in regression analysis, presented in the next section.

a)

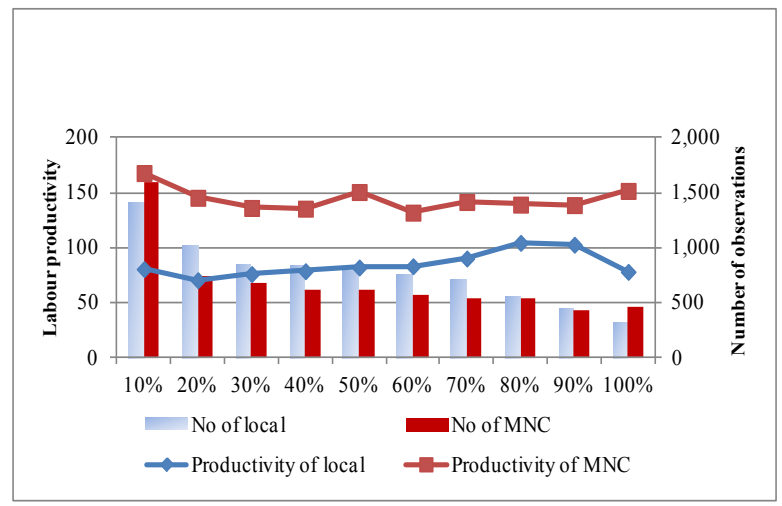

b)

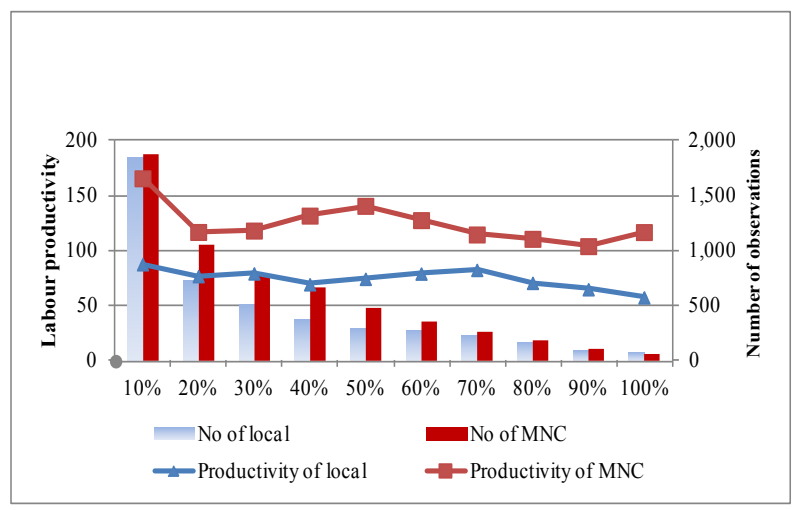

Fig. 3. Average labour productivity (in thousands of Euros) by levels of adjusted (a) and long-term (b) leverage

\section{Results}

In our panel regression analysis, we find support for the prediction that the relationship between leverage and labour productivity in the Baltic countries is non-linear (see Table 3 below). Namely, the results for Model 1 show that at low levels of adjusted leverage, increase in debt tends to bring along an increase in labour productivity, while in highly leveraged companies an increase in debt financing appears to be associated with a decrease in labour productivity.

This outcome is similar to Kale et al. (2007) who find a non-linear relationship between leverage and labour productivity based on a sample of US companies. Kale et al. (2007) 
Table 3. Regression results

\begin{tabular}{|c|c|c|c|c|c|c|}
\hline \multirow{2}{*}{$\begin{array}{l}\text { Labour } \\
\text { Productivity }\end{array}$} & \multicolumn{2}{|c|}{ No interaction terms } & \multicolumn{2}{|c|}{ With interaction terms } & \multicolumn{2}{|c|}{$\begin{array}{l}\text { Subsample with } \\
\text { LEV }>0\end{array}$} \\
\hline & $\begin{array}{l}\text { Adjusted } \\
\text { leverage } \\
(1)\end{array}$ & $\begin{array}{l}\text { Long-term } \\
\text { leverage } \\
(2)\end{array}$ & $\begin{array}{l}\text { Adjusted } \\
\text { leverage } \\
(3) \\
\end{array}$ & $\begin{array}{l}\text { Long-term } \\
\text { leverage } \\
\text { (4) }\end{array}$ & $\begin{array}{l}\text { Adjusted } \\
\text { leverage } \\
(5)\end{array}$ & $\begin{array}{l}\text { Long-term } \\
\text { leverage } \\
(6)\end{array}$ \\
\hline \multirow[t]{2}{*}{ GDP } & $0.40 *$ & $0.41 *$ & $0.40 *$ & $0.40^{*}$ & $0.52 * *$ & 0.50 \\
\hline & $(0.23)$ & $(0.23)$ & $(0.23)$ & $(0.23)$ & $(0.26)$ & $(0.33)$ \\
\hline \multirow[t]{2}{*}{ Leverage } & $0.15^{*}$ & 0.07 & $0.32 * * *$ & $0.21^{* *}$ & $0.25 * *$ & $0.21 *$ \\
\hline & $(0.08)$ & $(0.08)$ & $(0.10)$ & $(0.10)$ & $(0.12)$ & $(0.13)$ \\
\hline \multirow[t]{2}{*}{ Leverage $^{2}$} & $-0.37 * * *$ & $-0.33 * * *$ & $-0.51 * *$ & $-0.47 * * *$ & $-0.41 * * *$ & $-0.39 * *$ \\
\hline & $(0.08)$ & $(0.11)$ & $(0.11)$ & $(0.15)$ & $(0.13)$ & $(0.17)$ \\
\hline \multirow[t]{2}{*}{ Leverage $\cdot \mathrm{MNC}$} & & & $-0.36^{* *}$ & $-0.31^{*}$ & $-0.26^{*}$ & -0.11 \\
\hline & & & $(0.15)$ & $(0.16)$ & $(0.15)$ & $(0.18)$ \\
\hline \multirow[t]{2}{*}{$\begin{array}{l}\text { Leverage }^{2} \cdot \\
\text { MNC }\end{array}$} & & & $0.29 *$ & 0.33 & 0.18 & 0.07 \\
\hline & & & $(0.17)$ & $(0.22)$ & $(0.17)$ & $(0.24)$ \\
\hline \multirow[t]{2}{*}{$\begin{array}{l}\text { Credit } \\
\text { Constraints } \\
\end{array}$} & 0.10 & 0.10 & $0.28 * *$ & $0.31 * *$ & 0.13 & -0.05 \\
\hline & $(0.10)$ & $(0.10)$ & $(0.14)$ & $(0.14)$ & $(0.15)$ & $(0.17)$ \\
\hline \multirow[t]{2}{*}{ Cred $\cdot \mathrm{MNC}$} & & & $-0.32 * *$ & $-0.36^{* *}$ & -0.21 & -0.03 \\
\hline & & & $(0.15)$ & $(0.14)$ & $(0.16)$ & $(0.17)$ \\
\hline \multirow[t]{2}{*}{ Age } & 0.00 & 0,00 & -0.01 & -0.001 & -0.02 & 0,00 \\
\hline & $(0.03)$ & $(0.03)$ & $(0.03)$ & $(0.03)$ & $(0.03)$ & $(0.02)$ \\
\hline \multirow[t]{2}{*}{$\mathrm{Age}^{2}$} & 0.00 & 0.00 & 0.00 & 0.00 & 0.00 & 0.00 \\
\hline & $(0.00)$ & $(0.00)$ & $(0.00)$ & $(0.00)$ & $(0.00)$ & $(0.00)$ \\
\hline \multirow[t]{2}{*}{ Tangibility } & $-0.55 * * *$ & $-0.56 * * *$ & $-0.56 * * *$ & $-0.57 * * *$ & $-0.61 * * *$ & $-0.59 * * *$ \\
\hline & $(0.05)$ & $(0.05)$ & $(0.05)$ & $(0.05)$ & $(0.06)$ & $(0.07)$ \\
\hline \multirow[t]{2}{*}{ Size } & $0.34 * * *$ & $0.34 * * *$ & $0.34 * * *$ & $0.34 * * *$ & $0.28 * * *$ & $0.26 * * *$ \\
\hline & $(0.02)$ & $(0.02)$ & $(0.02)$ & $(0.02)$ & $(0.02)$ & $(0.02)$ \\
\hline \multirow[t]{2}{*}{$\mathrm{HHI}$} & -0.10 & -0.09 & -0.09 & -0.08 & -0.02 & 0,00 \\
\hline & $(0.15)$ & $(0.15)$ & $(0.16)$ & $(0.15)$ & $(0.17)$ & $(0.24)$ \\
\hline \multirow[t]{2}{*}{ Leverage $\cdot$ skill } & $0.10^{*}$ & 0.05 & $0.11 * *$ & 0.06 & 0.05 & -0.08 \\
\hline & $(0.06)$ & $(0.07)$ & $(0.06)$ & $(0.07)$ & $(0.06)$ & $(0.08)$ \\
\hline Constant & $1.82 * * *$ & $1.84 * * *$ & $1.85^{* * *}$ & $1.86^{* * *}$ & $2.26^{* * *}$ & $2.39 * * *$ \\
\hline
\end{tabular}


End of Table 3

\begin{tabular}{l|l|l|l|l|l|l}
\hline \multirow{2}{*}{$\begin{array}{l}\text { Labour } \\
\text { Productivity }\end{array}$} & \multicolumn{2}{l|}{ No interaction terms } & \multicolumn{2}{l}{ With interaction terms } & \multicolumn{2}{l}{$\begin{array}{l}\text { Subsample with } \\
\text { LEV >0 }\end{array}$} \\
\cline { 2 - 7 } & $\begin{array}{l}\text { Adjusted } \\
\text { leverage } \\
(1)\end{array}$ & $\begin{array}{l}\text { Long-term } \\
\text { leverage } \\
(2)\end{array}$ & $\begin{array}{l}\text { Adjusted } \\
\text { leverage } \\
(3)\end{array}$ & $\begin{array}{l}\text { Long-term } \\
\text { leverage } \\
(4)\end{array}$ & $\begin{array}{l}\text { Adjusted } \\
\text { leverage } \\
(5)\end{array}$ & $\begin{array}{l}\text { Long-term } \\
\text { leverage } \\
(6)\end{array}$ \\
\hline & $(0.25)$ & $(0.25)$ & $(0.25)$ & $(0.25)$ & $(0.28)$ & $(0.25)$ \\
\hline No of obs & 18,401 & 18,401 & 18,401 & 18,401 & 14,402 & 10,371 \\
\hline $\mathrm{R}^{2}$ & 0.92 & 0.92 & 0.92 & 0.92 & 0.93 & 0.93 \\
\hline $\begin{array}{l}\text { Company fixed } \\
\text { effects }\end{array}$ & yes & yes & yes & yes & yes & yes \\
\hline $\begin{array}{l}\text { Sector-year } \\
\text { interactions }\end{array}$ & yes & yes & yes & yes & yes & yes \\
\hline Year dummies & yes & yes & yes & yes & yes & yes \\
\hline
\end{tabular}

$*, * *$ and $* * *$ indicate significance at $10 \%, 5 \%$, and $1 \%$ level respectively. Robust standard errors in parentheses.

argue that debt functions as a disciplinary mechanism up to a certain breakpoint starting from where the threat of financial distress or underinvestment due to the debt overhang problem begins to outweigh the incentives from the bonding mechanism. We believe that the positive coefficient of leverage might also show that the lack of debt financing sets limits to companies' ability to increase sales and thereby hinders the achievement of productivity improvements through economies of scale in labour utilisation. In case of long-term leverage (Model 2) the relationship between leverage and labour productivity is also non-linear. The squared term of leverage is negative and significant while leverage remains insignificant, indicating that long-term leverage tends to have a negative impact on productivity.

Our results indicate that the relationship between financing and labour productivity is considerably different for MNCs compared to local companies. For adjusted leverage as well as long-term leverage (Models 3 and 4, respectively), the interaction term between leverage and the MNC dummy is negative and significant while the coefficient for the interaction term between squared leverage and $\mathrm{MNC}$ dummy is positive and significant for adjusted leverage and insignificant for long-term leverage. This implies that labour productivity of MNCs, in contrast to local companies, appears to be more linear and tends to decrease as a reaction to increased leverage. The relationship is illustrated in Figure 4.

The breakpoint leverage, starting from where the impact of adjusted leverage for local companies becomes negative, is $32 \%$, while the average level of adjusted leverage for local companies is $33 \%$ and the median value $27 \%$. Thus, for more than half of the observations, additional leverage might bring along improvements in labour productivity. On the other hand, for MNCs, additional leverage does not seem to have any positive 
impact on labour productivity. This outcome might indicate that the availability of debt financing does not considerably limit the productivity of MNCs operating in the Baltics unlike local companies. A possible explanation for the different impact of leverage on the labour productivity of MNCs might be that in their case the disciplinary role of debt is weaker compared to local companies. Belonging to a corporate group, MNCs might be potentially able to utilise intra-group financial resources and are therefore less dependent on external debt providers. As the size of the operations of the subsidiaries of multinational groups in the Baltic countries tends to be relatively small compared to the size of the entire group, providing financing for such operations is not likely to be significantly constrained. In some cases, maintaining presence in the Baltic market might be of higher priority for corporate groups than improving short-run results. Additionally, the part of financing that comes in the form of intra-group lending might not function as a monitoring device.
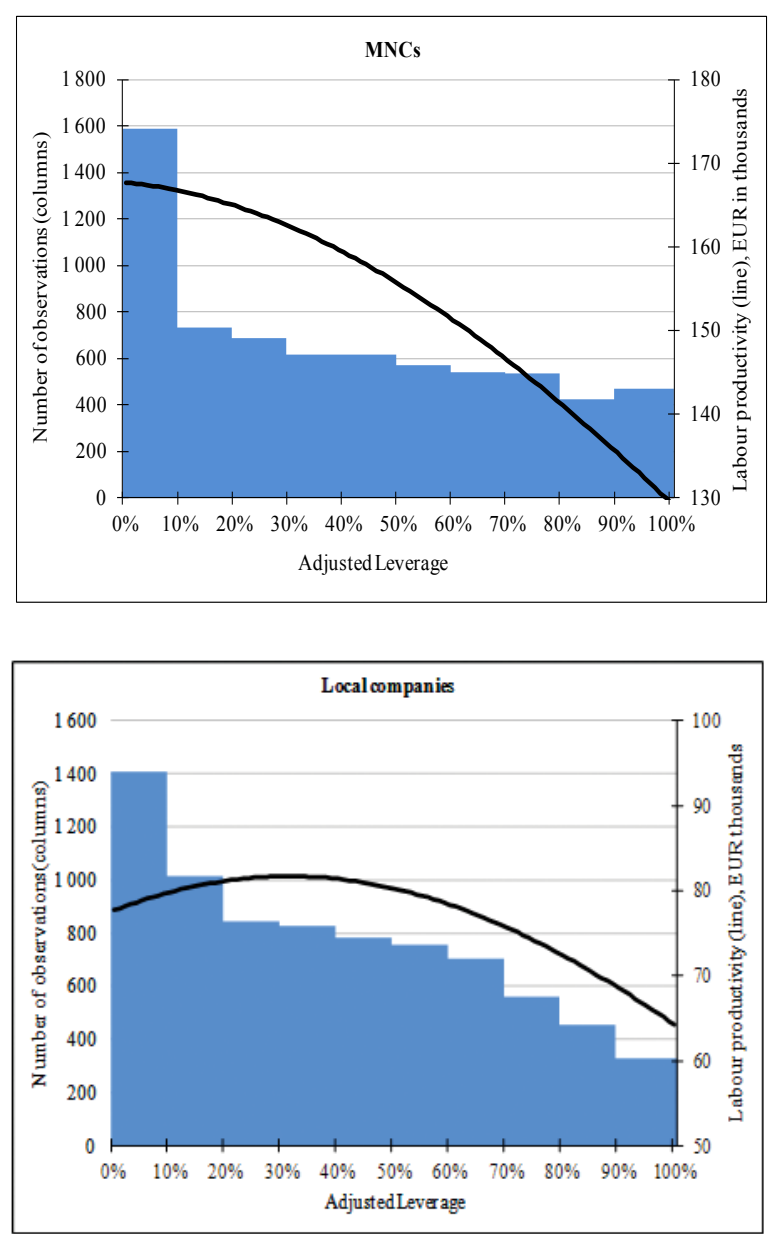

Fig. 4. Impact of adjusted leverage on labour productivity of MNCs and local companies 
The impact of perceived credit constraints on labour productivity is different from our expectations, or more specifically, this relationship seems to have a more complex nature than we expected. Namely, the perceived obstacles in obtaining credit appear to have a positive influence on the productivity of local companies and only a minor impact on the productivity of multinational companies. When credit constraints increased by 1 point in the four-point scale, labour productivity of local companies in our sample would increase by approximately $7 \%$. This implies that the perceived (and materialised) obstacles in accessing credit, combined with competitive pressure, are likely to force local companies to find ways to increase efficiency by using less workforce to generate a unit of sales. On the other hand, similar obstacles do not seem to put such a pressure on multinational companies as they generally tend to have a broader choice of financing sources in addition to third party credit, and can therefore more easily attract financing to support growth. As the descriptive statistics indicate, the average level of perceived credit constraints is higher for local companies compared to MNCs. Beck et al. (2002) have demonstrated that perceived financing constraints are generally higher for those companies which have a high demand for external financing either due to the growth opportunities or a lack of internal resources. High perceived credit constraints may therefore reflect that companies are active at the credit market and see opportunities for expansion. Empirical results of Avarmaa et al. (2011) also indicate a positive relationship between credit constraints and leverage in the local companies operating in the Baltic countries.

Interestingly, both perceived credit constraints and leverage appear to have a positive relation to labour productivity in local companies. While experienced obstacles in getting credit are related to productivity improvements, the ability to increase leverage also has a positive influence on productivity up to a certain point in local companies. A possible explanation to this somewhat puzzling result might be that limited financial resources, which constrain growth, motivate companies to look for ways of achieving the existing activity level with fewer resources. Avarmaa (2011) has found that credit constraints have a negative impact on sales growth in local companies operating in the Baltics, while the negative influence on sales growth of MNCs is relatively low. The positive impact of credit constraints on labour productivity in our study is therefore likely to indicate that productivity improvements are gained through increased efficiency rather than sales growth. However, in the circumstances where local companies are able to increase leverage despite the faced obstacles for getting credit, the increase of leverage enables to achieve further productivity improvements (i.e. higher sales per employee) through economies of scale.

As expected, GDP growth has a positive impact on labour productivity. Concerning the other control variables, the relationship between labour productivity and company size is positive, reflecting the existence of economies of scale in terms of labour productivity. A $1 \%$ change in assets appears to result in a $0.34 \%$ change in productivity.

We find the relationship between tangibility and labour productivity to be negative. In our sample, a $1 \%$ reduction in tangibility results in an increase of labour productivity by $0.56 \%$. This might be explained by the trade-off theory of capital structure (Kraus, 
Litzenberger 1973) whereby companies rich in intangible assets have less collateral, a higher bankruptcy risk and are thus less leveraged. At the same time, innovative companies are proved to be highly productive (Egger, Keuschnigg 2010). The interaction term between leverage and high-skilled industries is positive, supporting the argument that skill-intensive sectors seem to benefit more from higher leverage than others. This could be related to the fact that their tendency to innovate creates a need for higher financing while the innovative activities might not be transparent for outside agents, and innovative companies are therefore credit rationed (Egger, Keuschnigg 2010). However, we note that in our study, skill-intensive industries include more industries than the R\&D one.

Company age and the Herfindahl index remained insignificant in explaining labour productivity. In case of the Herfindahl index, this might be related to the shortcomings of proxying as described in Section 3.

We have tested robustness of the results by running the regression on a limited subsample where the leverage of observations is above zero. In case of adjusted leverage (Model 5), the outcome remained the same with the exception that the interaction term between MNC and squared leverage is insignificant in explaining labour productivity for the subsample, potentially explained by the small size of the subsample. For the same reason, the effect of credit constraints on labour productivity remained insignificant. Regarding long-term leverage (Model 6), the impact of leverage also remained the same while the interaction terms between leverage and MNC dummy as well as credit constraints remained insignificant since the sample size was almost two times smaller for this regression compared to the main sample.

\section{Conclusions}

Our findings contribute to the literature by showing that the relationship between leverage and labour productivity is non-linear. At low level of leverage an increase in leverage appears to be related to an improvement in labour productivity, and after a certain breakpoint leverage tends to have a negative impact on labour productivity. Overall, this finding supports the previous evidence by Kale et al. (2007).

We find the impact of leverage on labour productivity to be considerably different for MNCs and local companies operating in the Baltic countries. While there appears to be a positive concave relationship between leverage and labour productivity for local companies, the impact is slightly negative in case of MNCs. We show that at moderate levels of leverage (up to an adjusted leverage of $32 \%$ ) lending tends to have a positive impact on labour productivity of local companies in the Baltic countries. On the other hand, at high levels of leverage, there appears to be a considerable negative impact of leverage on labour productivity.

For MNCs, the impact of leverage on labour productivity tends to be more linear than for local companies and additional leverage does not seem to bring along any improvements in labour productivity. The different impact of leverage on MNCs can be explained by the weaker role of debt as a monitoring device and easier access to all forms of financing. 
While perceived credit constraints are positively related to the labour productivity of local companies, limited access to credit seems not to be a sufficient tool for sustainable productivity growth. The positive impact of credit constraints on labour productivity found in our study is likely to indicate that such productivity improvements are gained through higher efficiency rather than sales growth. In the circumstances where local companies are able to increase leverage despite the experienced obstacles for getting credit, the increase of leverage enables to achieve further productivity improvements.

Although the debt overhang problem is considered to be threatening the Baltic economies (Hertzberg 2010), additional leverage might bring along some improvements in labour productivity for many local companies. On the other hand, it is essential for companies to pay attention to the measures for avoiding excess borrowing as this appears to hinder productivity. Companies' unawareness of the critical level from where additional leverage starts to generate non-productive or non-sustainable growth may also be a key in understanding why some companies perform in a procyclical way, propagating economic booms and bubbles. This remains an interesting area for future research.

\section{Acknowledgements}

We are grateful to Professor Karsten Staehr and three anonymous referees as well as the participants of the $8^{\text {th }}$ International Conference on Applied Financial Economics and the $3^{\text {rd }}$ International Conference on Economies of Central and Eastern Europe for valuable comments. We are thankful to the Estonian Science Foundation (grant no ETF8796) and to the Doctoral School of Economics and Innovation, created under the auspices of the European Social Fund, for financial support.

\section{References}

Arratibel, O.; Heinz, F.; Martin, R.; Przybyla, M.; Rawdanowicz, L.; Serafini, R.; Zumer, T. 2007. Determinants of growth in the central and eastern European EU member states - a production function approach, Occasional Paper Series No 61. European Central Bank.

Avarmaa, M. 2011. Does leverage affect company growth in the Baltic countries?, Information and Finance. 21: 90-95. IACSIT Press.

Avarmaa, M.; Hazak, A.; Männasoo, K. 2011. Comparative analysis of the capital structures of multinational and local companies in the Baltic States, Baltic Journal of Economics 11(1): 125-145.

Beck, T.; Demigrüc-Kunt, A.; Maksimovic, V. 2002. Financing patterns around the world. The role of institutions, Policy Research Paper No 2905. The World Bank.

Bellak, C. 2004. How domestic and foreign firms differ and why does it matter?, Journal of Economic Surveys 18(4): 483-514. http://dx.doi.org/10.1111/j.0950-0804.2004.00228.x

Bijsterbosch, M.; Kolasa, M. 2009. FDI and productivity convergence in Central and Eastern Europe an industry-level investigation, Working Paper Series No 992. ECB.

Blomström, M.; Kokko, A. 1998. Multinational corporations and spillovers, Journal of Economic Surveys 12(2): 247-278.

Castellani, D.; Zanfei, A. 2004. Multinationals, Innovation and Productivity. Evidence from Italian Manufacturing Firms, University of Urbino [online], [cited 06 December 2010]. Available from Internet: http://www.fscpo.unict.it/pdf/Castellani\%20(paper).pdf 
Chen, M. 2010. Financial effects and firm productivity: evidence from Chinese manufacturing data, in $9^{\text {th }}$ Annual Postgraduate Conference. University of Nottingham [online], [cited 06 December 2010]. Available from Internet: www.nottingham.ac.uk/GEP.

Coricelli, F.; Driffeld, N.; Pal, S.; Roland, I. 2010. Leverage and productivity growth in emerging economies: is there a threshold effect?, Working Paper No. 10-21. Brunel University Economics and Finance Working Paper Series.

Dimelis, S.; Louri, H. 2002. Foreign ownership and production efficiency: a quantile regression analysis, Oxford Economic Papers 54: 449-469. http://dx.doi.org/10.1093/oep/54.3.449

Doms, M.; Jensen, B. 1998. Comparing wages, skills, and productivity between domestically and foreign owned manufacturing establishments in the United States, in Geography and Ownership as Bases for Economic Accounting. Chicago: Chicago University Press, 235-258.

Egger, P.; Keuschnigg, C. 2010. Innovation, trade, and finance, Working paper 2010-08. University of St. Gallen Working Paper Series.

Eurostat [online], [cited 12 February 2011]. Available from Internet: http://epp.eurostat.ec.europa. eu/portal/page/portal/eurostat/home/

Gatti, R.; Love, I. 2006. Does access to credit improve productivity? Evidence from Bulgarian firms, Policy Research Paper No. 3921. The World Bank.

Geršl, A.; Rubene, E.; Zumer, T. 2007. Foreign direct investment and productivity spillovers: updated evidence from the Central and Eastern European countries, Working Paper Series 8/2007. Czech National Bank.

Ghosh, S. 2009. Productivity and financial structure: evidence from Indian high-tech firms, Global Business Review 10(2): 261-278.

Ginevičius, R.; Čirba, S. 2009. Additive measurement of market concentration, Journal of Business Economics and Management 10(3): 191-198. http://dx.doi.org/10.3846/1611-1699.2009.10.191-198

Girma, S.; Greenaway, D.; Wakelin, K. 1999. Wages, productivity and foreign ownership in UK manufacturing, Research Paper No. 99/14. Centre for Research on Globalization and Labour Markets.

Globerman, S.; Ries, J.; Vertinsky, I. 1994. The economic performance of foreign affiliates in Canada, The Canadian Journal of Economics 27(1): 143-156. http://dx.doi.org/10.2307/135807

Greenaway, D.; Guariglia, A.; Yu, Z. 2009. The more the better? Foreign ownership and corporate performance in China, Research Paper No. 2009/05. University of Nottingham.

Greenhalgh, C.; Rogers, M. 2004. The value of innovation: the interaction of competition, R\&D and IP, Economics Series Working Papers: 192. University of Oxford, Department of Economics.

Hall, R.; Jones, C. 1999. Why do some countries produce so much more output per worker than others?, The Quarterly Journal of Economics 114(1): 83-116.

http://dx.doi.org/10.1162/003355399555954

Hazak, A.; Männasoo, K. 2010. Indicators of corporate default - an EU based empirical study, Transformations in Business \& Economics 9(1): 62-76.

Herzberg, V. 2010. Assessing the risk of private sector debt overhang in the Baltic countries, IMF Working Paper WP/10/250.

Hossain, F.; Jain, R.; Govindasamy, R. 2005. Financial structure, production and productivity: evidence from the U.S. food manufacturing industry, Agricultural Economics 33(S3): 399-410.

Huizinga, H.; Laeven, L.; Nicodame, G. 2008. Capital structure and international debt shifting, Journal of Financial Economics 88(1): 80-118. http://dx.doi.org/10.1111/j.1574-0864.2005.00080.x

Jensen, M.; Meckling, W. 1976. Theory of the firm: managerial behavior, agency costs, and ownership structure, Journal of Financial Economics 3(4): 305-360.

http://dx.doi.org/10.1016/0304-405X(76)90026-X 
Jog, V.; Tang, J. 2001. Tax reforms, debt shifting and tax revenues: multinational corporations in Canada, International Tax and Public Finance 8(1): 5-25.

http://dx.doi.org/10.1023/A:1008749415492

Kale, J.; Ryan, H.; Wang, L. 2007. Debt as a bonding mechanism: evidence from the relations between employee productivity, capital structure, and outside employment opportunities, in 18th Annual Conference on Financial Economics and Accounting, NYU [online], [cited 06 December 2010]. Available from Internet: http://w4.stern.nyu.edu/salomon/docs/conferences/Kale-RyanWang-.pdf

King, R.; Levine, R. 1993. Finance and growth: Schumpeter might be right, Quarterly Journal of Economics 108(3): 717-737. http://dx.doi.org/10.2307/2118406

Kraus, A.; Litzenberger, R. 1973. A state preference model of optimal financial leverage, Journal of Finance 28(4): 911-922. http://dx.doi.org/10.1111/j.1540-6261.1973.tb01415.x

Leung, D.; Meh, C.; Terajima,Y. 2008. Productivity in Canada: does firm size matter?, Bank of Canada Review (Autumn): 7-16.

Männasoo, K. 2008. Patterns of firm survival in Estonia, Eastern European Economics 46(4): 27-42. http://dx.doi.org/10.2753/EEE0012-8775460402

Moreno Badia, M.; Slootmaekers, V. 2008. The missing link between financial constraints and productivity, Discussion Paper 208/2008. LICOS Discussion Paper Series.

Myers, S. 1977. Determinants of corporate borrowing, Journal of Financial Economics 5(2): 147-175. http://dx.doi.org/10.1016/0304-405X(77)90015-0

Nucci, F.; Pozzolo, A.; Schivardi, F. 2005. Is firm's productivity related to its financial structure? Evidence from microeconomic data, Rivista di Politica Economica, SIPI Spa 95(1): 269-290.

Nunes, P.; Sequera, T.; Serrasqueiro, Z. 2007. Firms' leverage and labour productivity: a quantile approach in Portugese firms, Applied Economics 39(14): 1783-1788.

http://dx.doi.org/10.1080/00036840600707076

OECD. 2003. The Sources of Economic Growth in OECD Countries [online], [cited 06 December 2010]. Available from Internet: http://www.oecd.org/dac/ictcd/docs/otherdocs/OtherOECD_eco_growth.pdf.

Oulton, N. 1998a. Investment, capital and foreign ownership in UK manufacturing, Discussion Paper. No 141. London: National Institute of Economic and Social Research.

Oulton, N. 1998b. Labour productivity and foreign ownership in the UK, Discussion Paper No 143. London: National Institute of Economic and Social Research.

Pavitt, K. 1984. Sectoral patterns of technical change: towards a taxonomy and theory, Research Policy 13(6): 343-373. http://dx.doi.org/10.1016/0048-7333(84)90018-0

Pfaffermayr, M.; Bellak, C. 2000. Why foreign-owned firms are different. A conceptual framework and empirical evidence for Austria, Discussion Paper Series. Hamburgisches Welt-WirtschaftsArchiv (HWWA): Hamburg Institute of International Economics.

Pianta, M.; Bogliacino, F. 2008. The Impact of R\&D and Innovation on Economic Performance and Employment: a Quantitative Analysis Based on Innovation Survey Data. University of Urbino, Faculty of Economics.

Rajan, R.; Zingales, L. 1995. What do we know about capital structure? Some evidence from International Data, Journal of Finance 50(5): 1421-1460.

http://dx.doi.org/10.1111/j.1540-6261.1995.tb05184.x

Ross, S. 1977. The determination of financial structure: the incentive signaling approach, Bell Journal of Economics 8(1): 23-40. http://dx.doi.org/10.2307/3003485

Schadler, S.; Mody, A.; Abiad, A.; Leigh, D. 2006. Growth in the Central and Eastern European countries of the European Union, Occasional Paper No 252. IMF. 
Solow, R. M. 1956. A contribution to the theory of economic growth, Quarterly Journal of Economics 70(1): 65-94. http://dx.doi.org/10.2307/1884513

Syverson, C. 2010. What determines productivity, NBER Working Paper Series No 15712.

Vahter, P. 2004. The Effect of Foreign Direct Investment on Labour Productivity: Evidence from Estonia and Slovenia. Tartu University Press.

Vahter, P. 2006. Productivity in Estonian enterprises: the role of innovation and competition, Bank of Estonia Working Paper Series No. 7. Bank of Estonia.

Vahter, P.; Masso, J. 2006. Home versus host country effects of FDI: searching for new evidence of productivity spillovers, Working Paper No. 820. William Davidson Institute.

Weill, L. 2008. Leverage and corporate performance: does institutional environment matter?, Small Business Economics 30(3): 251-265. http://dx.doi.org/10.1007/s11187-006-9045-7 


\section{APPENDIXES}

\section{Appendix 1. Descriptive statistics for multinational and local companies (monetary values in thousands of Euros)}

\begin{tabular}{|c|c|c|c|c|c|c|c|c|}
\hline & & Mean & Median & $\mathrm{Sd}$ & Min & Max & $\begin{array}{l}\text { No of } \\
\text { obs }\end{array}$ & $\begin{array}{l}\text { Wilcoxon } \\
\text { rank-sum } \\
\text { test }(\mathrm{z})\end{array}$ \\
\hline \multirow[t]{2}{*}{ Total Assets } & Local & 1,959 & 749 & 5,473 & 0 & 174,424 & 9,282 & $-45.8 * * *$ \\
\hline & $\mathrm{MNC}$ & 5,673 & 1,933 & 12,658 & 1 & 272,140 & 9,119 & \\
\hline \multirow{2}{*}{$\begin{array}{l}\text { Long-term } \\
\text { Debt }\end{array}$} & Local & 294 & 17 & 1,620 & 0 & 64,669 & 9,282 & $8.6 * * *$ \\
\hline & $\mathrm{MNC}$ & 744 & 0 & 4,133 & 0 & 104,508 & 9,119 & \\
\hline \multirow{2}{*}{$\begin{array}{l}\text { Short-term } \\
\text { Debt }\end{array}$} & Local & 213 & 20 & 936 & 0 & 22,489 & 9,282 & $3.6 * * *$ \\
\hline & $\mathrm{MNC}$ & 510 & 7 & 1,996 & 0 & 79,583 & 9,119 & \\
\hline \multirow[t]{2}{*}{ Sales } & Local & 3,361 & 1,392 & 7,354 & 0 & 174,582 & 9,282 & $-46.7 * * *$ \\
\hline & $\mathrm{MNC}$ & 9,248 & 3,569 & 17,825 & 1 & 401,879 & 9,119 & \\
\hline \multirow[t]{2}{*}{ Net Profit } & Local & 192 & 55 & 797 & $-7,538$ & 39,981 & 9,282 & $-19.8 * * *$ \\
\hline & $\mathrm{MNC}$ & 471 & 123 & 1,816 & $-15,657$ & 49,357 & 9,119 & \\
\hline \multirow{2}{*}{$\begin{array}{l}\text { Adjusted } \\
\text { Leverage }\end{array}$} & Local & 0.33 & 0.27 & 0.29 & 0.00 & 1.00 & 9,282 & $10.8 * * *$ \\
\hline & $\mathrm{MNC}$ & 0.30 & 0.18 & 0.31 & 0.00 & 1.00 & 9,119 & \\
\hline \multirow{2}{*}{$\begin{array}{l}\text { Long-term } \\
\text { Leverage }\end{array}$} & Local & 0.11 & 0.03 & 0.16 & 0.00 & 0.99 & 9,282 & $18.0 * * *$ \\
\hline & $\mathrm{MNC}$ & 0.08 & 0.00 & 0.16 & 0.00 & 0.99 & 9,119 & \\
\hline \multirow{2}{*}{$\begin{array}{l}\text { Credit } \\
\text { Constraints }\end{array}$} & Local & 0.46 & 0.45 & 0.06 & 0.27 & 0.65 & 9,282 & $47.56^{* * *}$ \\
\hline & $\mathrm{MNC}$ & 0.39 & 0.39 & 0.09 & 0.21 & 0.71 & 9,119 & \\
\hline \multirow{2}{*}{$\begin{array}{l}\text { No of } \\
\text { employees }\end{array}$} & Local & 50 & 27 & 77 & 1 & 1,557 & 9,282 & $-13.3 * * *$ \\
\hline & MNC & 86 & 33 & 157 & 1 & 4,985 & 9,119 & \\
\hline \multirow{2}{*}{$\begin{array}{l}\text { Labour } \\
\text { Productivity }\end{array}$} & Local & 83 & 39 & 126 & 0 & 1,024 & 9,282 & $-39.2 * * *$ \\
\hline & $\mathrm{MNC}$ & 152 & 86 & 176 & 0 & 1,030 & 9,119 & \\
\hline \multirow[t]{2}{*}{ Age } & Local & 9.0 & 9.3 & 4.2 & 0.1 & 17.0 & 9,282 & $5.7 * * *$ \\
\hline & $\mathrm{MNC}$ & 8.6 & 8.8 & 4.1 & 0.1 & 17.0 & 9,119 & \\
\hline \multirow[t]{2}{*}{ Tangibility } & Local & 0.33 & 0.30 & 0.24 & 0.00 & 1.00 & 9,282 & $22.4 * * *$ \\
\hline & $\mathrm{MNC}$ & 0.26 & 0.17 & 0.25 & 0.00 & 1.00 & 9,119 & \\
\hline
\end{tabular}

$* * *$ denotes significance at $1 \%$ level. 
Appendix 2. Number of observations per industry

\begin{tabular}{l|l|l|l|l|l|l|l|l|l}
\hline & & $\begin{array}{l}\text { Agriculture, } \\
\text { forestry } \\
\text { and fishing }\end{array}$ & Mining & $\begin{array}{l}\text { Cons- } \\
\text { truction }\end{array}$ & $\begin{array}{l}\text { Manufac- } \\
\text { turing }\end{array}$ & $\begin{array}{l}\text { Whole- } \\
\text { sale } \\
\text { trade }\end{array}$ & $\begin{array}{l}\text { Retail } \\
\text { trade }\end{array}$ & Services & Total \\
\hline Local & $\begin{array}{l}\text { Labour } \\
\text { productivity }\end{array}$ & 29 & 43 & 49 & 48 & 177 & 57 & 48 & 83 \\
\hline & No of obs. & 418 & 29 & 1,657 & 2,520 & 2,450 & 1,333 & 875 & 9,282 \\
\hline & $\%$ of obs. & $5 \%$ & $0 \%$ & $18 \%$ & $27 \%$ & $26 \%$ & $14 \%$ & $9 \%$ & $100 \%$ \\
\hline MNC & $\begin{array}{l}\text { Labour } \\
\text { productivity }\end{array}$ & 99 & 41 & 115 & 78 & 258 & 87 & 89 & 152 \\
\hline & No of obs. & 95 & 110 & 429 & 2,965 & 3,589 & 612 & 1,319 & 9,119 \\
\hline & $\%$ of obs. & $1 \%$ & $1 \%$ & $5 \%$ & $33 \%$ & $39 \%$ & $7 \%$ & $14 \%$ & $100 \%$ \\
\hline Total & $\begin{array}{l}\text { Labour } \\
\text { productivity }\end{array}$ & 42 & 41 & 63 & 64 & 225 & 67 & 73 & 117 \\
\hline & No of obs. & 513 & 139 & 2,086 & 5,485 & 6,039 & 1,945 & 2,194 & 18,401 \\
\hline & $\%$ of obs. & $3 \%$ & $1 \%$ & $11 \%$ & $30 \%$ & $33 \%$ & $11 \%$ & $12 \%$ & $100 \%$ \\
\hline
\end{tabular}

Appendix 3. Pairwise correlations between variables

\begin{tabular}{|c|c|c|c|c|c|c|c|c|c|}
\hline & $\begin{array}{l}\text { Labour } \\
\text { productivity }\end{array}$ & $\begin{array}{l}\text { GDP } \\
\text { Growth }\end{array}$ & $\begin{array}{l}\text { Adjusted } \\
\text { Leverage }\end{array}$ & $\begin{array}{l}\text { Long-term } \\
\text { Leverage }\end{array}$ & $\begin{array}{l}\text { Credit } \\
\text { Constraints }\end{array}$ & $\begin{array}{l}\text { Tangi- } \\
\text { bility }\end{array}$ & Size & Age & HHI \\
\hline $\begin{array}{l}\text { Labour } \\
\text { productivity }\end{array}$ & 1.00 & & & & & & & & \\
\hline $\begin{array}{l}\text { GDP } \\
\text { Growth }\end{array}$ & $-0.01 * *$ & 1.00 & & & & & & & \\
\hline $\begin{array}{l}\text { Adjusted } \\
\text { Leverage }\end{array}$ & $-0.03 * * *$ & $0.04 * * *$ & 1.00 & & & & & & \\
\hline $\begin{array}{l}\text { Long-term } \\
\text { Leverage }\end{array}$ & $-0.09 * * *$ & $0.05 * * *$ & $0.68 * * *$ & 1.00 & & & & & \\
\hline $\begin{array}{l}\text { Credit } \\
\text { Constraints }\end{array}$ & $-0.09 * * *$ & $0.05 * * *$ & $0.07 * * *$ & $0.07 * * *$ & 1.00 & & & & \\
\hline Tangibility & $-0.32 * * *$ & $0.01 * *$ & $0.31 * * *$ & $0.36^{* * *}$ & $0.09 * * *$ & 1.00 & & & \\
\hline Size & $0.15 * * *$ & $-0.02 * *$ & $0.06 * * *$ & $0.06 * * *$ & $-0.03 * * *$ & $0.10 * * *$ & 1.00 & & \\
\hline Age & $-0.06 * * *$ & $-0.09 * * *$ & $-0.10 * * *$ & $-0.05 * * *$ & 0.01 & $0.09 * * *$ & $0.09 * * *$ & 1.00 & \\
\hline HHI & $-0.13 * * *$ & $-0.02 * *$ & $0.03 * * *$ & $0.04 * * *$ & $0.04 * * *$ & $0.16 * * *$ & $0.15^{* * *}$ & $0.03 * * *$ & 1.00 \\
\hline
\end{tabular}

$*, * *$ and $* * *$ denote significance at $10 \%, 5 \%$, and $1 \%$ level respectively. 
Mari AVARMAA. PhD in Financial Economics, is involved in research and teaching at Tallinn School of Economics and Business Administration at Tallinn University of Technology. Her main areas of interest are corporate capital structure and multinational financial management.

Aaro HAZAK. Senior Researcher at Tallinn School of Economics and Business Administration at Tallinn University of Technology, holds a PhD in Financial Economics. His current research primarily focuses on the micro and macro level drivers of companies' financial decisions and company failure.

Kadri MÄNNASOO. PhD in Economics, works as Senior Researcher at Tallinn School of Economics and Business Administration at Tallinn University of Technology. Her research focus is company survival and financial system stability, tackling the endogenous and exogenous factors that impact the fragility of real sector firms and financial institutions. 